\title{
Reptiles as principal prey? Adaptations for durophagy and prey selection by jaguar (Panthera onca)
}

\author{
Everton B.P. Miranda ${ }^{\mathrm{a}, \mathrm{b}}$, Jorge F.S. de Menezes ${ }^{\mathrm{c}, \mathrm{d}}$ and Marcelo L. Rheingantz \\ aLaboratório de Herpetologia, Universidade Federal de Mato Grosso, Cuiabá, Brazil; 'bPrograma de \\ Pós-graduação em Ecologia e Conservação da Biodiversidade, Universidade Federal de Mato Grosso, \\ Cuiabá, Brasil; 'Laboratório de Ecologia e Conservação de Populações, Universidade Federal do Rio de \\ Janeiro, Rio de Janeiro, Brasil; 'Mitrani Department of Desert Ecology, Ben Gurion University of the Negev, \\ Beersheba, Israel
}

\begin{abstract}
We examined the evidence supporting the hypothesis that jaguars (Panthera onca) have morphological and behavioural adaptations to facilitate reptile predation. Jaguars' head and bite features show adaptations to durophagy (consumption of hard-integumented prey) that are very unusual within the genus Panthera. These include: thick canines, well-developed head muscles and a fatal bite directed to braincase or nape. These characteristics have been previously considered an adaptation for the consumption of reptilian prey, whose thick integument poses a challenge to predation. Although causation of any trait as result of natural selection is hard to demonstrate with ecological evidence, its consequences can be suggested and predictions made. Here, through a review of the literature on jaguar predatory habits, we tallied the evidence for saurophagy against environmental characteristics correlated with jaguar predation on reptiles. We offer a new explanation for the presence of those traits, based on the selection patterns, prey abundances and main predation habits over the geographic range of the jaguar. We believe that these features allow jaguars to overcome dangerous and/or armoured prey by dispatching them rapidly through a bite to the head or nape. Reptile consumption is restricted to areas of high reptile abundance while dangerous or armoured prey is consistently preyed upon throughout the jaguar's distribution, and selected even when their abundance is low. This questions the validity of the saurophagy hypothesis. We believe that these results are relevant to jaguar conservation and management, because some of the main prey species are severely threatened over their range, and because threatened reptiles are also consumed as prey.
\end{abstract}

\section{ARTICLE HISTORY}

Received 16 February 2015

Accepted 21 January 2016

\section{KEYWORDS}

Dangerous prey;

saurophagy; Tayassuidae;

Xenarthra

\section{Introduction}

Cranial morphological characteristics are one of the main constraints on the food acquisition capacities of a species (Hutchinson 1957; Tseng et al. 2014). In the genus

CONTACT Everton B.P. Miranda mirandaebp@gmail.com $\otimes$ Laboratório de Herpetologia, Universidade Federal de Mato Grosso, Cuiabá, Brazil 
Panthera (Felidae), dietary limitations are also of special concern in terms of conservation management. Loss of prey species to poaching has been listed as one of the main threats to big cat long-term population viability (Ramakrishnan et al. 1999; Graham et al. 2005). When compared to other large cats, jaguars (Panthera onca) possess a suite of unusual morphological adaptations (Seymour 1989). These include (1) a head that is very large relative to the body size; (2) canines with low lateral compression and a cylindrical shape in horizontal section (in other big cats they are laterally compressed: Valkenburgh and Ruff 1987; Christiansen and Adolfssen 2005); (3) highly developed masseter and temporal muscles (Christiansen and Adolfssen 2005); and (4) a body with a general corpulence (Seymour 1989). Combined, these features give jaguars one of the strongest bites relative to body size in the entire order Carnivora (Valkenburgh and Ruff 1987; Wroe et al. 2005). The killing behaviour of jaguars is unique for a large cat: instead of biting the ventral portion of the prey neck and killing by suffocation, as other pantherines do (Schaller 1967, 1972), jaguars target large prey and use a direct bite to the skull or into the neck vertebrae, to damage the central nervous system and immediately incapacitate the prey (Schaller and Vasconcelos 1978; Crawshaw and Quigley 2002). Although other pantherines can also kill with a bite to the neck or head, this is either rare and/or used only on smaller prey species (Schaller 1967, 1972).

The first to propose a hypothesis to explain this features was Emmons (1987). Noting that data collected at the Cocha Cashu research station showed important levels of saurophagy (reptile-eating), and collating additional observation of tortoise predation in French Guiana, she suggested jaguar characteristic anatomical features and behavioural characteristics were to allow durophagy (the behaviour of animals that consume hardtegument organisms), so providing a way to overcome the defences of armoured reptiles (Emmons 1987, 1989). Although jaguars are the only large cats that prey regularly on reptiles (Da Silveira et al. 2010), and these sometimes can dominate their diet (Ramalho 2006), one cannot rule out the possibility that jaguar preference for reptiles is a local idiosyncrasy. Most reports of jaguars with reptile-dominated diets come from floodplains (Emmons 1987; Scognamillo et al. 2003; Ramalho 2006), where large armoured reptiles like crocodilians and turtles are abundant (Marcellini 1979; Alho 1985; Da Silveira and Thorbjarnarson 1999; Mourão et al. 2000; Scognamillo et al. 2003). This suggests that reptile consumption by jaguars may be an opportunistic behaviour, and does not show that it is responsible for the suite of characters mentioned above.

Ecological evidence cannot identify specific agents of natural selection. Nor can it reveal the functional relationships that result in the morphological and behavioural traits (Young and Brodie 2004 and comments therein), that ultimately allow jaguars to prey on armoured reptiles. Emmons' hypothesis, therefore, is speculative in that it does not allow any inference as to whether morphological and behavioural traits are a cause or a consequence of adaptations to predation modes earlier in the evolution of the lineage. Although it is difficult to show the agents and forms of selection that play a role in the evolution of any feature (Grant et al. 1976; Endler 1980), it is possible to demonstrate their consequences (Genovart et al. 2010). Consequently, we proposed to test with ecological data the consequences of this phenotype on jaguar predation patterns.

Regardless of its origin, this syndrome might reduce the risks involved in preying on dangerous animals. Biting through the skull or vertebrae is an effective means of swiftly disabling dangerous or armoured prey (Mukherjee and Heithaus 2013). Such a killing 
technique reduces manipulation time and decreases the risk involved in predation (Eisenberg and Leyhausen 1972). However, this requires the appropriate apparatus, since applying force sufficient to break thick bones implies considerable wear and stress on the canines, with a consequent increase in the risk of tooth breakage (Valkenburgh and Ruff 1987). The process of predation on some jaguar diet species also seems to carry a high potential risk of injury. Peccaries (Tayassuidae) are social animals known for collectively attacking predators (Bissonette 1982; Kiltie and Terborgh 1983). Apart from jaguars themselves (Soares et al. 2006; Azevedo et al. 2010), they are one of the few animals known to kill jaguars (Scognamillo et al. 2003). Killing a peccary by suffocation takes time and would leave the predator vulnerable to attack by the rest of herd. On the other hand, a braincase bite would kill swiftly or, at least, severely disable the prey animal. In consequence, even if the herd attacks, the jaguar can retreat, then subsequently scavenge the corpse.

Given the frequent scars and fresh wounds that jaguar show on camera-trap photographs, defensive attacks by peccary against jaguar may not be uncommon (Everton Miranda, pers. obs.). Other than peccaries, giant anteaters (Mymercophaga tridactyla) can also pose a serious threat to predators. These animals may reach $43 \mathrm{~kg}$ (Koster 2008a), and have fore claws that can inflict a predator with a fatal wound. Although undocumented in field studies, accounts of large cats and anteaters dying in mutual embrace are relatively common in South American folklore (Bertassoni 2012). Additional evidence of the risk offered by predating anteaters is that they are considered a threat to hunting dogs, which they often kill (Koster 2008b). To administer a throat bite, any predator would have to position itself ventrally, relative to the prey, making them immediately vulnerable to the hypertrophied claws and associated powerful musculature. This would not be the case if the predator bites the back of the head. Armadillos also pose a challenge to predators that kill with a suffocating bite, since they have short necks, are fast burrowing and are armed with large claws. Again, a morphology adapted to durophagy, like that in jaguars, would be appropriate for killing such armoured prey. Capybaras (Hydrochoerus hydrochaeris), whose primary defence is running to the water, can also react viciously to predation with bites, and are capable of decapitating anacondas (Eunectes murinus; Rivas 2000). All that could be overcome with a bite to central nervous system. Moreover, all the species mentioned above have low running capabilities, possess poor senses for detecting predators at large distances, and therefore cannot rely on escaping to avoid predation.

Given these reasons, we hypothesise that the suite of morphological and behavioural characters shown by jaguars allows them to more effectively kill dangerous and armoured prey, rather than specifically reptiles, as suggested by Emmons $(1987,1989)$. We propose that although possessing these characters allows jaguars to kill reptiles more easily, they will do so only when reptiles achieve sufficiently high abundances to become profitable prey. To test these hypotheses we: (1) investigated whether jaguar preyed upon Tayasuidae and Xenarthra more frequently than over other prey types; (2) evaluated whether jaguar preyed on reptiles more frequently than other prey species, as predicted by Emmons's hypothesis; (3) analysed whether reptile predation is higher on floodplains, indicating use may be abundance-dependent, and therefore opportunistic; and, (4) measured diet selectivity for each group when studies provided jaguar prey abundance data, so verifying whether predation on dangerous and/or armoured prey is 
opportunistic or selective. Finally, (5) we tested whether cougar (Puma concolor) - a similar-sized species where durophagy features in skull are missing - preyed on dangerous/armoured prey to a lesser degree compared to jaguars.

\section{Methods}

Using Google Scholar, Web of Science, Scopus and Scielo search engines, we conducted an extensive search of the literature concerning interactions of jaguars and their prey. We also consulted other researchers for unpublished data and literature unrevealed by online searches. In our search, we used the following keywords: 'jaguar', 'Panthera onca' and 'onça-pintada' combined with 'diet', 'feeding habits', 'food habits', 'habitos alimentarios' and 'dieta'. This allowed us to find published and unpublished data in English, Portuguese and Spanish. From each study, we recorded the study area geographical coordinates, and the percentage of occurrence of each taxon in the diet. We calculated the percentage of occurrence using the percentage of total faeces in which a certain prey category was found, divided by the number of prey occurrences of the whole study (see Ackerman et al. 1984 for more details about the method).

We grouped data collected from these studies coarsely according to phylogenetic relationships, assuming members of these taxa possess similar anti-predator strategies. We used the following groups: Xenarthra, Tayassuidae, Glires (Rodentia and Lagomorpha orders), Carnivora, cattle (Bos), Cervidae, Reptilia, Aves, Primates and tapirs (Tapirus). We did not consider domestic animals other than cattle, since there were few records of such attacks.

Our data were not normally distributed (Komogorov-Smirnov test, $p<0.05$ ). Hence, in order to test whether xenarthrans and peccaries or reptiles were preyed more frequently than other groups, we used two Wilcoxon signed-rank tests.

To test whether the proportion of reptiles preyed by jaguars was higher on floodplains, where they are more abundant in nature, we performed a third Wilcoxon signedrank test. We excluded data from coastal study sites a priori as they are used by turtles as nesting sites, and we were uncertain whether jaguar behaviour under such conditions of ephemeral abundance would be comparable to their behaviour at floodplain sites. In addition, the small sample size $(n=2)$ precluded using them as unique and separate category for this analysis, but we summarised all items in Table 1.

Several studies have conducted high-quality dietary analysis based on prey occurrence in jaguar scats (e.g. Ramalho 2006; Azevedo and Murray 2007; Foster et al. 2010). However, most of these lack comparable estimates of prey abundances or cover only partial prey assemblages. In order to test whether higher frequencies of dangerous and/ or armoured prey in jaguar prey were the result of selection, rather than only availability, we carried out a Jacobs selection index (Jacobs 1974) on only six scat-based studies that had data on prey densities obtained using linear transects. Any index ideally satisfies all the criteria needed to adequately evaluate food selection, but we choose Jacobs because it is one of the most used and allows more comparisons with the published literature (Hayward and Kerley 2005; Hayward et al. 2006, 2012).

Finally, we tested whether cougar preyed dangerous/armoured prey at lower levels compared to jaguars using a Mann-Whitney test over the 10 studies that had collected data for both species. We did this test using only peccaries and armadillos 
Table 1. Jaguar predation on a variety of taxa shown as frequency of occurrence. Note the effect of floodplains on reptile predation and the consistent high predation on xenarthrans and peccaries. Taber et al. (1997) worked in two study areas.

\begin{tabular}{|c|c|c|c|c|c|c|c|c|c|c|c|c|}
\hline Source & Xena & Tayassuidae & Glires & Carnivora & Cattle & Cervidae & Birds & Primates & Tapir & Reptiles & Habitat & $\mathrm{n}$ \\
\hline 1 & 32.4 & NO & 0 & NO & 2.7 & NO & 2.7 & 8.1 & NO & 54.1 & Floodplain & 29 \\
\hline 2 & 2.9 & 17.1 & 20 & 2.9 & NO & 5.7 & 11.4 & 2.9 & 0 & 37.1 & Floodplain & 25 \\
\hline 4 & 7.7 & 20.1 & 4.1 & 5.1 & 34.2 & 7.2 & 2.6 & 0.5 & 0 & 18.6 & Floodplain & 160 \\
\hline 5 & 16.7 & 16.7 & 4.1 & 12.4 & 8.4 & 0 & 4.1 & 12.4 & 8.3 & 16.7 & Floodplain & 25 \\
\hline 9 & 9.6 & 40.8 & 21.5 & 4.4 & 7.1 & 9.6 & 0 & 0 & 0 & 7.1 & Floodplain & 42 \\
\hline 10 & 5.1 & 6 & 24.5 & 9.8 & 12.2 & 28.5 & 6.8 & 0 & 0 & 7 & Floodplain & 149 \\
\hline 19 & 20 & 9.7 & 21.3 & 17.5 & 17.5 & 10.9 & 0.6 & 1.3 & 0 & 1.3 & Floodplain & 134 \\
\hline 6 & 24.5 & 27.4 & 7.9 & 22.3 & 0 & 2.9 & 2.9 & 1.4 & 0.7 & 10 & Forest & 101 \\
\hline 7 & 6 & 21.5 & 21.1 & 21.6 & 8.3 & 10.8 & 1.2 & 0 & 0 & 9.6 & Forest & 51 \\
\hline 8 & 10 & 42.3 & 9.9 & 8.9 & 0 & 10 & 10 & 1.1 & 0 & 7.8 & Forest & 73 \\
\hline 11 & 14.5 & 16.1 & 0 & 17.8 & NO & 42 & 3.2 & 0 & NO & 6.4 & Forest & 50 \\
\hline 12 & 6.2 & 50.1 & 25 & 0 & 0 & 12.5 & 0 & 0 & NO & 6.2 & Forest & 16 \\
\hline 16 & 14.9 & 44.6 & 4.3 & 19.1 & NO & 8.5 & 4.3 & 0 & 0 & 4.4 & Forest & 37 \\
\hline 17 & 67 & 5.7 & 14.3 & 2.2 & 0 & 6.8 & 0.5 & 0 & 0 & 3.4 & Forest & 228 \\
\hline 18 & 50.7 & 13.6 & 5.6 & 17 & 3.1 & 3.1 & 5.4 & 0 & 0 & 1.4 & Forest & 322 \\
\hline 20 & 21.6 & 24.8 & 5.7 & 34.5 & NO & 6.9 & 5.3 & 1.2 & 0 & 0 & Forest & 206 \\
\hline 21 & 36.7 & 16 & 12.2 & 22.1 & NO & 8.5 & 2.8 & 1.8 & 0 & 0 & Forest & 76 \\
\hline 24 & NO & 7.4 & 11.1 & 11.1 & 44.4 & 25.9 & 0 & NO & NO & 0 & Forest & 27 \\
\hline 25 & 20.8 & 8.3 & 16.6 & 25.1 & 0 & 12.5 & 0 & NO & 16.6 & 0 & Forest & 25 \\
\hline 26 & 34.5 & 27.6 & 24.2 & 6.8 & 0 & 6.9 & 0 & 0 & 0 & 0 & Forest & 23 \\
\hline 27 & 62.8 & 3.7 & 18.8 & 7.4 & NO & 7.4 & 0 & 0 & 0 & 0 & Forest & 18 \\
\hline 3 & 25.4 & 20.2 & 5 & 5 & NO & 5 & 5 & 10.1 & 0 & 24.3 & Forest $^{\mathrm{a}}$ & 22 \\
\hline 14 & 18.1 & 67.1 & 3 & 0 & NO & 0 & 3 & 3 & 0 & 5.8 & Forest $^{\mathrm{a}}$ & 18 \\
\hline 13 & 18.3 & 8.2 & 36.8 & 0 & 0 & 26.5 & 4.1 & 0 & 0 & 6.1 & Savanna & 58 \\
\hline 15 & 18.4 & 60 & 5 & 0 & 0 & 0 & 3.3 & 0 & 8.4 & 5 & Savanna & 41 \\
\hline 22 & 9.6 & 1.9 & 52.1 & 1.9 & 0 & 28.9 & 1.9 & 0 & 3.7 & 0 & Savanna & 40 \\
\hline 23 & 67.7 & 5 & 9.9 & 9.9 & 2.4 & 0 & 0 & 0 & 5 & 0 & Savanna & 35 \\
\hline 28 & 30.5 & 34.8 & 0 & 4.3 & 0 & 13 & 13 & 0 & 4.3 & 0 & Savanna & 18 \\
\hline
\end{tabular}

NO: does not occur at the study site.

${ }^{\text {a }}$ Sea turtle nesting beach at the study site.

Sources: 1. Ramalho (2006); 2. Emmons (1987); 3. Chinchilla (1997); 4. Perilli (2010); 5. Nuno (2007); 6. Garla et al. (2001); 7. Azevedo (2008); 8. Crawshaw et al. (2004); 9. Scognamillo et al. (2003); 10. Azevedo and Murray (2007); 11. Núñez et al. (2000); 12. Tirelli (2010); 13. Taber et al. (1997); 14. Carrillo et al. (2009); 15. McBride et al. (2010); 16. Aranda and Sánchez-Cordero (1996); 17. Rabinowitz and Nottingham (1986); 18. Foster et al. (2010); 19. Porfírio (2009); 20. Hernández (2008); 21. Novack et al. (2005); 22. Taber et al. (1997); 23. Sollmann et al. (2013); 24. Rosas-Rosas et al. (2008); 25. Mendoza (2005); 26. Weckel et al. (2006); 27. Oliveira et al. (2010); 28. Silveira (2004).

(of whatever species). Other prey fitting the dangerous/armoured category were represented in few sites. This precluded meaningful comparisons because sample size would be small. We performed the test by comparing the percentage of diet composed by either peccaries or armadillos for each study site.

\section{Results}

\section{Review}

We considered 36 studies of jaguar diet covering 40 study areas. Of these, $95 \%(n=38)$ analysed faeces, $20 \%$ both carcasses and faeces $(n=8)$, and $5 \%$ carcasses only $(n=2)$. The mean number of fecal samples per site was 26 (range: 7-322). The mean number of carcasses analysed was 74 (range: 5-438); however, as carcass samples were almost exclusively from floodplains (seven of 10 sites), with few sites to compare with this group, we discarded such data. As a Spearman test revealed a correlation between sample size and trophic diversity measured by the Shannon $\mathrm{H}^{\prime}$ index, we only used the 
28 studies with at least 16 samples. When using only studies with 16 or more samples, we found no effect of the sample size on the diversity of prey species.

\section{Saurophagy vs dangerous/armoured prey hypothesis}

Our analyses showed xenarthrans and peccaries to be the most common prey in the majority of the studies, while reptiles made a marginal contribution to the prey species data (Table 1). Comparison between peccary plus xenarthran predation vs all other groups confirmed this pattern $(\mathrm{W}=2082, p<0.0001, \mathrm{n}=28)$. Comparison between reptiles vs all other groups showed no significant difference $(\mathrm{W}=3507, p=0.85, \mathrm{n}=28)$.

\section{The role of floodplains}

Diet studies from floodplains had higher predation on reptiles than those from other habitat types ( $\mathrm{W}=117, p<0.001, \mathrm{n}=9$ ). All incidences of crocodilian predation occurred on floodplains, as did virtually all aquatic turtle predation.

\section{Prey selection}

Jacob's selection index revealed positive selection for xenarthrans and peccaries. However, capybaras were also a highly selected prey species. Caiman appear among prey species with the lowest selection when compared to their abundance, along with several other prey taxa that are highly vigilant and/or use speed as an antipredator strategy (Figure 1).

\section{Jaguar and cougar diet comparison}

Jaguar preyed over armadillos and peccaries in higher levels compared to cougars (Figure 2). The Mann-Whitney test shows a marginally significant effect on armadillos $(\mathrm{W}=49, \mathrm{p}=0.08)$ and a statistically significant effect on peccaries $(\mathrm{W}=96.5, \mathrm{p}<0.05)$.

\section{Discussion}

Although a subject of recent research interest (Da Silveira et al. 2010; Azevedo and Verdade 2012; Veríssimo et al. 2012; Guilder et al. 2015), the factors underlying jaguar predation on reptiles remain unresolved. Caiman abundance in the Pantanal, although regionally heterogeneous, is estimated overall at 35 million non-hatchling animals (Mourão et al. 2000), representing almost half of all biomass of terrestrial vertebrates available to jaguars (De Azevedo and Murray 2007). On the floodplains at Mamirauá, the caiman population can reach up to 115 non-hatchling animals per kilometre of riparian habitat (Da Silveira and Thorbjarnarson 1999). This level of abundance, and the virtual absence of other large-sized prey (Do Amaral 2012), drives jaguar to rely on caiman as their main prey. The Venezuelan Llanos also has a large caiman population and high densities of freshwater turtles and tortoises. Together the biomass of these reptiles exceeds all other potential prey combined (Scognamillo et al. 2003). However, even in these habitats, reptiles were preyed upon at low frequencies compared to their 


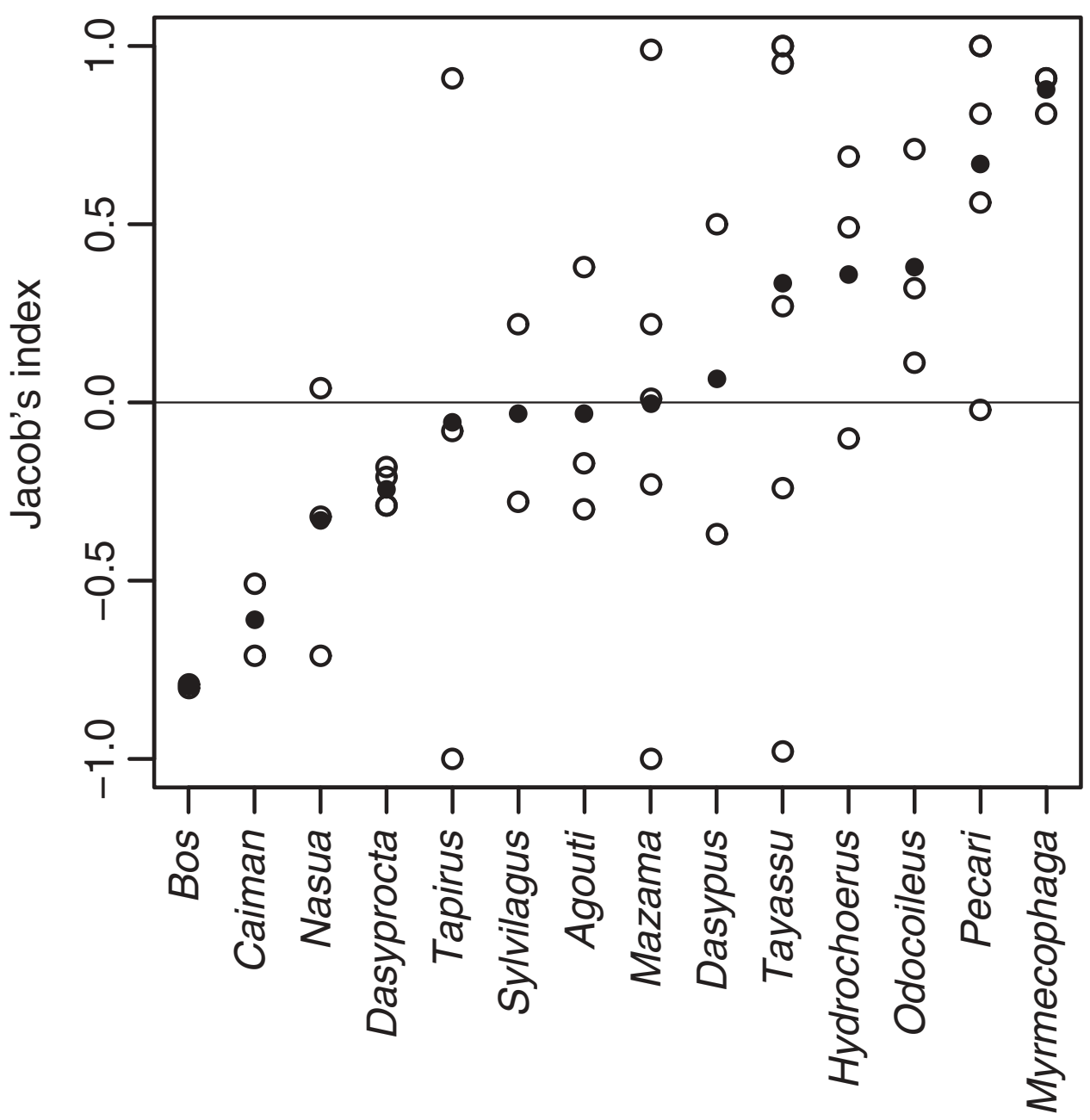

Figure 1. Jaguar (Panthera onca) preference for different prey species. Preference was measured with a Jacob index based on the number of individuals of a given species consumed compared to abundance data in number of individuals. Data was pooled from reviewed literature on the subject. Each datum is an average of each study. A value of 0 indicates that jaguars consume this resource with a frequency proportional to its relative abundance in the environment. A positive value indicates that it consumes more than expected by chance. A negative value indicates consumption occurred at a value less than expected by random (avoidance).

overwhelming abundance. In these same areas, peccaries and anteaters dominate the diet (Table 1).

Except for predation of Chelonoidis (formerly Geochelone) tortoises, heavy predation on Chelonia by jaguars appears to be restricted to places where mass nesting occurs. This is true for both freshwater and marine turtles (Chinchilla 1997; Salera Jr 2005). Additional research on jaguar predation patterns at sea turtle nesting sites is necessary to reveal the importance of these animals as prey species of coastal-living jaguars, as currently the small number of studies at sea turtle nesting beaches $(n=2)$ precludes any 


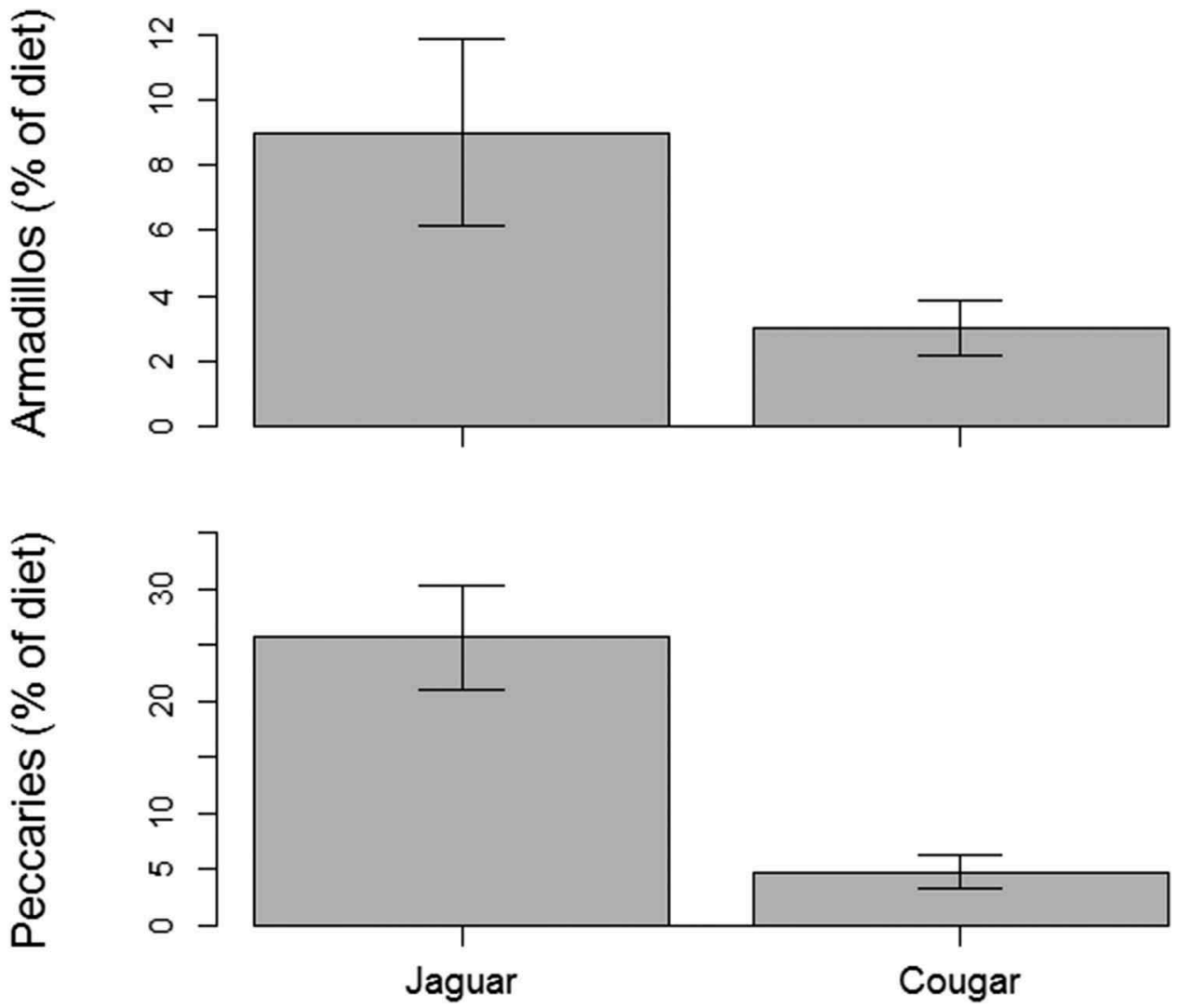

Figure 2. Percentage of Jaguar (Panthera onca) diet composed by peccaries or armadillos compared with cougars (Puma concolor). Jaguar prey more extensively over armoured and dangerous prey. Data were pooled from reviewed literature where faeces of cougars and jaguars were collected at the same site. Bars represents means while whiskers represent standard errors for each prey group.

additional analysis. As jaguars share sea turtle carcasses and/or increase carcass use when they are rare, they may be an important seasonal resource (Guilder et al. 2015).

Jaguars may also kill reptiles regularly on floodplains and at turtle nesting beaches. Such saurophagy is not known for any other big cat. To better understand the drivers associated with jaguar predation, we suggest that researchers collect information on prey occurrence in scats, and also quantitative data on prey abundances. To ensure comparability, these should use linear transects (sensu Buckland et al. 1993). Since avian (rheas, cracids: Aranda and Sánchez-Cordero 1996; Azevedo and Murray 2007), mammalian and reptilian prey can all be important in jaguar diets, abundance measurements should include all possible prey species. This task may be easier at turtle nesting sites, since nesting turtles can be monitored reliably with indirect methods (Troëng and Rankin 2005; Mogollones et al. 2010). Selective predation on specific turtle sizes should be verified, since a preference for larger animals has been shown to occur when jaguars attack caiman (Azevedo and Verdade 2012). If it also occurs in turtles, such selection could be problematic for turtle conservation, since large females are those with the greatest reproductive output (Bjorndal and Carr 1989). Such parameters are useful when 
considering management to minimise turtle losses when populations or species are threatened. One remedial measure that could reduce the impact of predation is the collection of eggs from turtles killed via plastron removal (Salera Jr 2005). This could avoid the complete loss of the eggs, especially if subsequently combined with egg husbandry. Data on abundance of prey species (including nesting turtles) will allow the formation and implementation of best management practices in areas where jaguar predatory habits are in conflict with the management of other species of conservation concern. For example, Arroyo-Arce (2014) suggested that predation on turtles began with the decline of terrestrial prey. Thus, protecting turtles in this ecosystem may lead to a reduction in jaguar survival by depriving it of its main food source. Knowing turtle abundances relative to other jaguar prey would indicate whether turtle management can be applied without detriment to jaguar survival.

Peccaries have previously been identified as a preferred food source for jaguars (Aranda, 1994; Mendes Pontes and Chivers 2007; Azevedo and Conforti 2008). Their large size and high densities in Neotropical ecosystems make them suitable main prey candidates. Indeed, in some populations, they are known to drive jaguar movements (Mendes Pontes and Chivers 2007). Jaguar historical distribution in North America is similar to that of peccaries (Aranda, 1994; Gongora et al. 2011). Additionally, several morphological traits of peccaries, such as vertebrae fusion and the thick mane of bristly hair above the nape, suggest selection of these traits as deterrents to predators attacking the braincase or vertebrae. Here, we show that jaguars appear to be strongly dependent on peccaries, selectively preying on them wherever both species occur. Peccaries are two of the Neotropical game species most frequently hunted by poachers (Bodmer 1995). Thus, the level of exploitation is of special concern for peccary conservation, especially when we consider peccaries are threatened or have disappeared over a large portion of their original range (Altrichter et al. 2012; Canale et al. 2012). This is so even inside conservation areas that are important for continued jaguar survival (SalomPérez et al. 2007; Azevedo and Conforti 2008; Paviolo et al. 2008).

While xenarthrans appear to suffer an even stronger selection as prey (Figure 1), being the smallest-sized species in most jaguar studies usually leads to little documented predation. In areas such as the Brazilian Cerrado, where giant anteaters are common, they can constitute up to $70 \%$ of jaguar prey (Sollmann et al. 2013). But more studies in other savannah areas are needed to confirm whether this is a general form of prey selection. In areas where jaguar body size is smaller, such as Central America, small xenarthrans (mainly armadillos and lesser anteaters) become the main prey alongside peccaries (Novack et al. 2005; Foster et al. 2010). In areas such as the Caatinga dry forests of Brazil, where jaguars are also small (Perez 2008), we hypothesise that they too will probably be heavily dependent on small xenarthrans as food source, just as occurs in Central America. As suggested elsewhere (Hayward et al. 2015), these patterns may have had interesting consequences in the recent past as a great diversity of xenarthrans disappeared during the Pleistocene extinctions. Several of them, such as Holmesina, Neosclerocalyptus, Nothrotheriops and Pampatherium, were within the prey size range for jaguar. The extinct giant jaguar Panthera onca augusta (Schultz et al. 1985) could have been a predator on these species, and then shrunk into the size of the modern form after the extinctions. Certainly, similar processes have been documented for other 
carnivores following Pleistocene extinction of their prey base (wolves and coyotes; Meachen and Samuels 2012).

Other species of large cats also prey on dangerous animals. This can be done by methods other than quickly dispatching them with a central nervous system bite, as jaguars do. Lions (Panthera leo), for instance, kill buffalo in groups where some members restrain it physically while others can kill with a fatal bite directed to the throat/muzzle; meanwhile, they rapidly retreat if threatened by the nearby herd members (Schaller 1972). Another way of dealing with dangerous prey is killing mostly juveniles. With softer constitution than adults, the younger ones can be killed with a central nervous system bite even if the predator lacks the adequate apparatus for durophagy. Preferential predation of juvenile prey has been observed in cougars preying on peccaries (Foster et al. 2010), and amur tigers (Panthera tigris altaica) preying on boars (Miller et al. 2013).

Cougars' preference for juveniles further reinforces our hypothesis. This is the mechanism by which cougars kill the amount of peccaries observed in Figure 1 (Scognamillo et al. 2003; Foster et al. 2010), while jaguars concentrate predation on adult animals, further corroborating our hypothesis. Regarding the greater consumption of dangerous/armoured prey by jaguars, one could argue that this difference can be attributed to the size differences between jaguars and cougars. Cougar would prey on juveniles as the latter are compatible with cougars' size. However, cougars can kill prey much larger than peccaries (Iriarte et al. 1990). And armadillos, by contrast, are inside the prey size range of cougars but, being armoured, are rarely killed by them in comparison with the jaguars' toll on this same prey kind.

Our results indicate that the jaguar predatory apparatus allows effective killing of dangerous and armoured prey. It permits jaguars to successfully subdue reptiles whose main antipredator strategy uses morphological adaptations in the form of toughened skin and thickened skull and vertebral bones. We have also shown that saurophagy is restricted to areas of high reptile abundance, and believe that the highly strengthened integuments of caimans and turtles impose formidable obstacles to predation. The singular predation habits of the jaguar seem to have evolved to overcome a specific and well-developed suite of defensive adaptations possessed by their prey. This suggests that peccaries are preferred jaguar prey and may be essential for their persistence. In addition, xenarthrans are frequently selected, and giant anteaters can become an important prey item in open areas when they are common. Finally, rather than closing the questions regarding links between morphological adaptations and prey selection in jaguar, our work offers a new starting point where a multi-disciplinary approach combining ecology, evolution, morphology, palaeontology and natural history can help understand predation in this iconic species.

\section{Acknowledgements}

We acknowledge Emiliano Ramalho and Rahel Sollmann who kindly sent us additional literature, the existence of which we were unaware. Adrian Barnett kindly reviewed the English. We also acknowledge colleagues from the Laboratório de Ecologia e Conservação de Populações of Universidade Federal do Rio de Janeiro for discussions and suggestions for this work. 


\section{Disclosure statement}

No potential conflict of interest was reported by the authors.

\section{Funding}

One scholarship from the Conselho Nacional de Desenvolvimento Científico e Tecnológico [109603/2012-5] supported this research.

\section{References}

Ackerman BB, Lindzey FG, Hemker TP. 1984. Cougar food habits in southern Utah. J. Wildl. Manage. 48:147-155.

Alho CJR. 1985. Conservation and management strategies for commonly exploited Amazonian turtles. Biol Conserv. 32:291-298.

Altrichter M, Taber A, Beck H, Reyna-Hurtado R, Lizarraga L, Keuroghlian A, Sanderson EW. 2012. Range-wide declines of a key Neotropical ecosystem architect, the near threatened white-lipped peccary Tayassu pecari. Oryx. 46:87-98.

Aranda M. 1994. Importancia de los pecaríes (Tayassu spp.) en la alimentación del jaguar (Panthera onca) [Importance of pecari in jaguar feeding]. Acta Zoológica Mex. 62:11-22.

Aranda M, Sánchez-Cordero V. 1996. Prey spectra of jaguar (Panthera onca) and puma (Puma concolor) in tropical forests of Mexico. Stud Neotrop Fauna Environ. 31:65-67.

Arroyo-Arce S. 2014. Habitat features influencing jaguar Panthera onca (Carnivora: felidae) occupancy in Tortuguero National Park, Costa Rica. Rev Biol Trop. 62:1449-1458.

Azevedo FCC. 2008. Food habits and livestock depredation of sympatric jaguars and pumas in the Iguacu National Park area, south Brazil. Biotropica. 40:494-500.

Azevedo FCC, Costa RL, Concone HVB, Pires-da Silva A, Verdade LM. 2010. Cannibalism among Jaguars (Panthera onca). Southwest Nat. 55:597-599.

Azevedo FCC, Conforti VA. 2008. Decline of peccaries in a protected subtropical forest of Brazil: toward conservation issues. Mammalia. 72:82-88.

Azevedo FCC, Murray DL. 2007. Spatial organization and food habits of jaguars (Panthera onca) in a floodplain forest. Biol Conserv. 137:391-402.

Azevedo FCC, Verdade LM. 2012. Predator-prey interactions: jaguar predation on caiman in a floodplain forest. J Zool. 286:200-207.

Bertassoni A. 2012. Perception and popular reports about giant anteaters (Myrmecophaga tridactyla Linnaeus, 1758) by two Brazilian traditional communities. Edentata. 10:13-17.

Bissonette JA. 1982. Ecology and social behavior of the collared peccary in Big Bend National Park. Washington (TX): United States department of interior, Scientific Monograph series, 16. Available from: http://www.nps.gov/parkhistory/online_books/science/16.pdf

Bjorndal KA, Carr A. 1989. Variation in clutch size and egg size in the green turtle nesting population at Tortuguero, Costa Rica. Herpetologica. 288:181-189.

Bodmer RE. 1995. Managing Amazonian wildlife: biological correlates of game choice by detribalized hunters. Ecol Appl. 5:872-877.

Buckland ST, Anderson DR, Burnham KP, Laake JL, others. 1993. Distance sampling: estimating abundance of biological populations. London: Chapman \& Hall.

Canale GR, Peres CA, Guidorizzi CE, Gatto CAF, Kierulff MCM. 2012. Pervasive defaunation of forest remnants in a tropical biodiversity hotspot. PLoS One. 7:e41671.

Carrillo E, Fuller TK, Saenz JC. 2009. Jaguar (Panthera onca) hunting activity: effects of prey distribution and availability. J Trop Ecol. 25:563-567.

Chinchilla FA. 1997. La dieta del jaguar (Panthera onca), el puma (Felis concolor) y el manigordo (Felis pardalis) (Carnivora; Felidae) en el Parque Nacional Corcovado, Costa Rica [Diet of jaguar, puma and ocelot in the Corcovado National Park, Costa Rica]. Rev Biol Trop. 45:1223-1230. 
Christiansen P, Adolfssen JS. 2005. Bite forces, canine strength and skull allometry in carnivores (Mammalia, Carnivora). J Zool. 266:133-151.

Crawshaw PG, Quigley HB. 2002. Hábitos alimentarios del jaguar y el puma en el Pantanal, Brasil, con implicaciones para su manejo y conservación [Fedding habits of jaguar and puma in Pantanal, Brazil, with its implications to management and conservation]. In: Medellín RA, Equihua C, Chetkiewicz CLB, Crawshaw PG, Rabinowitz A, Redford KH, Robinson JG, Sanderson EW, Taber AB, editors. El jaguar en el nuevo Milen. México (DF): Universidad Nacional Autónoma de México, Wildlife Conservation Society y Fondo de Cultura Económica; p. 223-235.

Crawshaw PG, Mahler JK, Indrusiak C, Cavalcanti SM, Leite-Pitman MRP, Silvius KM. 2004. Ecology and conservation of the jaguar (Panthera onca) in Iguaçu National Park, Brazil. In: Silvius KM, Bodmer RE, Fragoso JMV, editors. People in nature: wildlife conservation in South and Central America. New York: Columbia University Press; p. 286-296.

Da Silveira R, Thorbjarnarson JB. 1999. Conservation implications of commercial hunting of black and spectacled caiman in the Mamirauá Sustainable Development Reserve, Brazil. Biol Conserv. 88:103-109.

Da Silveira R, Ramalho EE, Thorbjarnarson JB, Magnusson WE. 2010. Depredation by jaguars on caimans and importance of reptiles in the diet of jaguar. J Herpetol. 44:418-424.

Do Amaral JV. 2012. Caça de animais silvestres nas reservas de desenvolvimento sustentável Mamirauá e Amanã [Wild animal hunt in Mamirauá and Amanã reserves for suitanable development]. Belo Horizonte: Universidade Federal de Minas Gerais.

Eisenberg JF, Leyhausen P. 1972. The phylogenesis of predatory behavior in mammals. Z Tierpsychol. 30:59-93.

Emmons LH. 1987. Comparative feeding ecology of felids in a neotropical rainforest. Behav Ecol Sociobiol. 20:271-283.

Emmons LH. 1989. Jaguar predation on chelonians. J Herpetol. 23:311-314.

Endler JA. 1980. Natural selection on color patterns in Poecilia reticulata. Evolution. 34:76-91.

Foster RJ, Harmsen BJ, Valdes B, Pomilla C, Doncaster CP. 2010. Food habits of sympatric jaguars and pumas across a gradient of human disturbance. J Zool. 280:309-318.

Garla RC, Setz EZF, Gobbi N. 2001. Jaguar (Panthera onca) Food habits in Atlantic Rain Forest of Southeastern Brazil. Biotropica. 33:691-696.

Genovart M, Negre N, Tavecchia G, Bistuer A, Parpal L, Oro D. 2010. The young, the weak and the sick: evidence of natural selection by predation. PLoS One. 5:e9774.

Gongora J, Reyna-Hurtado R, Beck H, Taber A, Altrichter M, Keuroghlian A. 2011. Pecari tajacu. IUCN Red List Threat Species [Internet]. [cited 2015 Jun 1]. Available from: http://dx.doi.org/10.2305/ IUCN.UK.2011-2.RLTS.T41777A10562361.en.

Graham K, Beckerman AP, Thirgood S. 2005. Human-predator-prey conflicts: ecological correlates, prey losses and patterns of management. Biol Conserv. 122:159-171.

Grant PR, Grant BR, Smith JN, Abbott IJ, Abbott LK. 1976. Darwin's finches: population variation and natural selection. Proc Natl Acad Sci. 73:257-261.

Guilder J, Barca B, Arroyo-arce S, Gramajo R, Salom-pérez R. 2015. Jaguars (Panthera onca) increase kill utilization rates and share prey in response to seasonal fluctuations in nesting green turtle (Chelonia mydas mydas) abundance in Tortuguero National Park, Costa Rica. Mamm Biol [Internet]. 80:65-72. doi:10.1016/j.mambio.2014.11.005

Hayward MW, Henschel P, O'Brien J, Hofmeyr M, Balme G, Kerley GIH. 2006. Prey preferences of the leopard (Panthera pardus). J Zool. 270:298-313.

Hayward MW, Jedrzejewski W, Jedrzejewska B. 2012. Prey preferences of the tiger Panthera tigris. J Zool. 286:221-231.

Hayward MW, Kamler J, Montgomery RA, Newlove A, Rostro-Garcia S, Sales L, Van Valkenburgh B. 2015. Prey preferences of the jaguar Panthera onca reflect the post-Pleistocene demise of large prey. Front Ecol Evol. 3:148.

Hayward MW, Kerley GIH. 2005. Prey preferences of the lion (Panthera leo). J Zool [Internet]. 267:309-322. doi:10.1017/S0952836905007508 
Hernández CGE. 2008. Dieta, uso de hábitat y patrones de actividad del puma (Puma concolor) y el jaguar (Panthera onca) en la selva maya [Diet, use of hábitat and activity patterns of puma and jaguar on the mayan jungle]. Rev Mex Mastozoología Nueva Época. 12:113-130.

Hutchinson GE. 1957. Concluding remarks. Cold Spring Harb Symp Quant Biol. 22:415-427. doi:10.1101/SQB.1957.022.01.039

Iriarte JA, Franklin WL, Johnson WE, Redford KH. 1990. Biogeographic variation of food habits and body size of the America puma. Oecologia. 185:190-85.

Jacobs J. 1974. Quantitative measurement of food selection. Oecol. 14:413-417.

Kiltie RA, Terborgh J. 1983. Observations on the behavior of rain forest peccaries in Perú: why do White-lipped Peccaries form herds? Z Tierpsychol. 62:241-255.

Koster JM. 2008a. Giant anteaters (Myrmecophaga tridactyla) killed by hunters with dogs in the Bosawas Biosphere Reserve, Nicaragua. Southwest Nat. 53:414-416.

Koster JM. 2008b. Hunting with dogs in Nicaragua: an optimal foraging approach. Curr Anthropol. 49:935-944.

Marcellini DL. 1979. Activity patterns and densities of Venezuelan caiman Caiman crocodilus and pond turtles Podocnemis vogli. In: Eisenberg JF, editor. Vertebrate Ecology in the Northern Neotropics. Washington (DC): Smithsonian Institution Press; p. 263-271.

McBride R, Giordano A, Ballard WB. 2010. Note on the winter diet of jaguars Panthera onca in the Paraguaian transitional Chaco. Bellbird. 5:4-10.

Meachen JA, Samuels JX. 2012. Evolution in coyotes (Canis latrans) in response to the megafaunal extinctions. Proc Natl Acad Sci. 109:4191-4196.

Mendes Pontes AR, Chivers DJ. 2007. Peccary movements as determinants of the movements of large cats in Brazilian Amazonia. J Zool. 273:257-265.

Mendoza MGP. 2005. Habitos alimetarios de Panthera onca y Puma concolor en la Sierra Madre de Chiapas, México. Ciudad de México [Thesis; Feeding habits of Panthera onca and Puma concolor in Sierra Madre de Chiapas, Mexico]: Instituto de Historia Natural y Ecología.

Miller CS, Hebblewhite M, Petrunenko YK, Seryodkin IV, DeCesare NJ, Goodrich JM, Miquelle DG. 2013. Estimating Amur tiger (Panthera tigris altaica) kill rates and potential consumption rates using global positioning system collars. J Mammal. 845:855-894.

Mogollones SC, Rodríguez DJ, Hernández O, Barreto GR. 2010. A demographic study of the arrau turtle (Podocnemis expansa) in the Middle Orinoco River, Venezuela. Chelonian Conserv Biol. 9:79-89.

Mourão G, Coutinho M, Mauro R, Campos Z, Tomás W, Magnusson W. 2000. Aerial surveys of caiman, marsh deer and pampas deer in the Pantanal Wetland of Brazil. Biol Conserv. 92:175-183.

Mukherjee S, Heithaus MR. 2013. Dangerous prey and daring predators: a review. Biol Rev. 88:550563.

Novack AJ, Main MB, Sunquist ME, Labisky RF. 2005. Foraging ecology of jaguar (Panthera onca) and puma (Puma concolor) in hunted and non-hunted sites within the Maya Biosphere Reserve, Guatemala. J Zool. 267:167-178.

Núñez R, Miller B, Lindzey F. 2000. Food habits of jaguars and pumas in Jalisco, Mexico. J Zool. 252:373-379.

Nuno AMG. 2007. Conserving Carnivores: A. Attitudes of Portuguese high school students towards carnivores. B. Feeding habits of the jaguar: local and regional perspectives [Master thesis]. Leeds: University of Leeds.

Oliveira GC, Keller C, Prado DM. 2010. Composição da dieta de Panthera onca e Puma concolor em quatro localidades da Amazônia central e setentrional [Diet composition of Panthera onca and Puma concolor in four localities in central and northern Amazon]. Manaus (Brazil): Instituto Nacional de Pesquisas da Amazônia.

Paviolo A, De Angelo CD, Di Blanco YE, Di Bitetti MS. 2008. Jaguar Panthera onca population decline in the upper Paraná Atlantic forest of Argentina and Brazil. Oryx. 42:554-561.

Perilli MLL. 2010. Ecologia alimentar da onça-pintada (Panthera onca) na região sul do Pantanal utilizando análise de fezes- uma comparação com o método direto de telemetria GPS [Master thesis; Jaguar food ecology in the Southern region of Patanal using faeces analysis 
- a comparison with GPS telemetry]. Campo Grande: Universidade Federal do Mato Grosso do Sul.

Perez SEA. 2008. Ecologia da onça-pintada nos parques nacionais Serra da Capivara e Serra das Confusões, Piauí [Thesis; Ecology of jaguars and courgars in Serra da Capiva and Serra das Confusões National Parks]. Brasília: Universidade de Brasília.

Porfírio GEDO. 2009. Ecologia alimentar da onça-pintada (Panthera onca) na sub-região do Pantanal de Miranda, MS [Master thesis; Food ecology of jaguar in Miranda pantanal subregion, Mato grosso do Sul state]. Campo Grande: Universidade Federal do Mato Grosso do Sul.

Rabinowitz AR, Nottingham Jr BG. 1986. Ecology and behaviour of the jaguar (Panthera onca) in Belize, Central America. J Zool. 210:149-159.

Ramakrishnan U, Coss RG, Pelkey NW. 1999. Tiger decline caused by the reduction of large ungulate prey: evidence from a study of leopard diets in southern India. Biol Conserv. 89:113-120.

Ramalho EE. 2006. A dieta e o uso do habitat da onça-pintada (Panthera onca) em uma área de várzea, Reserva de Desenvolvimento Sustentável Mamirauá, Amazônia Central, Brasil [Master thesis; Diet and habitat use of jaguar in riverbanks on the Mamirauá reserve for sustainable development]. Manaus (Brazil): Instituto Nacional de Pesquisas da Amazônia.

Rivas JA. 2000. The life history of the green anaconda (Eunectes murinus), with emphasis on its reproductive biology [Ph.D. dissertation]. Knoxville: University of Tennessee.

Rosas-Rosas OC, Bender LC, Valdez R. 2008. Jaguar and puma predation on cattle calves in northeastern Sonora, Mexico. Rangel Ecol Manag. 61:554-560.

Salera Jr. G. 2005. Avaliação da biologia reprodutiva, predação natural e importância social em quelônios com ocorrência na bacia do Araguaia [Master thesis; Evaluation of reproductive biology, natural predation and social importance of chelonians with occurrence in the Araguaia basin]. Palmas: Tocantins' Federal University.

Salom-Pérez R, Carrillo E, Sáenz JC, Mora JM. 2007. Critical condition of the jaguar Panthera onca population in Corcovado National Park, Costa Rica. Oryx. 41:51-56.

Schaller GB. 1967. The deer and the tiger. Chicago: University of Chicago Press.

Schaller GB. 1972. The Serengeti lion: a study of predator-prey relations. Chicago: University of Chicago Press.

Schaller GB, Vasconcelos JMC. 1978. Jaguar predation on capybara. Zeitschrift für SaugetierkundeInternational J Mamm Biol. 43:296-301.

Schultz CB, Martin LD, Schultz MR. 1985. A Pleistocene jaguar from north-central Nebraska. Trans. Nebr. Acad. Sci. Affil. Soc. 8:93-98.

Scognamillo D, Maxit IE, Sunquist M, Polisar J. 2003. Coexistence of jaguar (Panthera onca) and puma (Puma concolor) in a mosaic landscape in the Venezuelan llanos. J Zool. 259:269-279.

Seymour KL. 1989. Panthera onca. Mamm. Species. 340:1-9.

Silveira L. 2004. Ecologia comparada e conservação da onça-pintada (Panthera onca) e onça-parda (Puma concolor), no Cerrado e Pantanal [Ph.D. dissertation; Comparative ecology and conservation of jaguar and puma on Cerrado and Pantanal]. Goiânia: Universidade Federal de Goiás.

Soares TN, Telles MPC, Resende LV, Silveira L, Jácomo ATA, Morato RG, Diniz-Filho JAF, Eizirik E, Brondani RPV, Brondani C. 2006. Paternity testing and behavioral ecology: A case study of jaguars (Panthera onca) in Emas National Park, Central Brazil. Genet Mol Biol. 29:735-740.

Sollmann R, Betsch J, Furtado MM, Hofer H, Jácomo ATA, Palomares F, Roques S, Tôrres NM, Vynne C, Silveira L. 2013. Note on the diet of the jaguar in central Brazil. Eur J Wildl Res. 59:445-448.

Taber AB, Novaro AJ, Neris N, Colman FH. 1997. The food habits of sympatric jaguar and puma in the Paraguayan Chaco. Biotropica. 29:204-213.

Tirelli FP. 2010. Análise comparativa de nichos tróficos de carnívoros (Mammalia, Carnivora) da região de alta floresta, estado do Mato Grosso, Brasil [Master thesis; Comparative analysis of carnivore thropic niches in alta floresta regions, Mato Grosso state]. Porto Alegre: Universidade Federal do Rio Grande do Sul.

Troëng S, Rankin E. 2005. Long-term conservation efforts contribute to positive green turtle Chelonia mydas nesting trend at Tortuguero, Costa Rica. Biol Conserv. 121:111-116. 
Tseng ZJ, Wang X, Slater GJ, Takeuchi GT, Li Q, Liu J, Xie G. 2014. Himalayan fossils of the oldestknown pantherine establish ancient origin of big cats. Proc R Soc B Biol Sci. 281:20132686.

Valkenburgh BV, Ruff CB. 1987. Canine tooth strength and killing behaviour in large carnivores. J Zool. 212:379-397.

Veríssimo D, Jones DA, Chaverri R, Meyer SR. 2012. Jaguar Panthera onca predation of marine turtles: conflict between flagship species in Tortuguero, Costa Rica. Oryx. 46:340-347.

Weckel M, Giuliano W, Silver S. 2006. Cockscomb revisited: jaguar diet in the Cockscomb Basin Wildlife Sanctuary, Belize1. Biotropica. 38:687-690.

Wroe S, McHenry C, Thomason J. 2005. Bite club: comparative bite force in big biting mammals and the prediction of predatory behaviour in fossil taxa. Proc R Soc B Biol Sci. 272:619-625.

Young KV, Brodie ED. 2004. How the horned lizard got its horns. Science. 304:65. 